\title{
KAJIAN VISUAL DESAIN KARAKTER PADA MASKOT KOTA MALANG
}

\author{
Dimas Rifqi Novica ${ }^{1}$, Ima Kusumawati Hidayat ${ }^{2}$ \\ ${ }^{1,2}$ Program Studi Animasi, Jurusan Seni dan Desain Universitas Negeri Malang \\ dimas.novica.fs@um.ac.id ${ }^{1}$, ima.hidayat.fs@um.ac.id ${ }^{2}$
}

\begin{abstract}
An appeal is needed to divert the audience's attention to the design, even only for a moment. Those feature found in all fields of design, especially character design. One example of character design is a mascot. Malang is the first city that has mascot made with ideal procedures, the collaboration result of ADGI (Asosiasi Desain Grafis Indonesia) Malang Chapter with Barenlitbang Malang City. Osi and Ji are Malang City mascot with anthropomorphism forms from lions and Manyar birds as a symbol of Malang. This study examines the design of mascot characters using design character principles, namely: silhouette, shape, proportion and pose. The data of this research obtained from observations, interviews, and documentation of the mascot character design of Malang City assessed by qualitative methods with a visual analysis approach. The four design principles reinforce the overall meaning of the visual language contained in the mascot character design so that the appeal is high towards the target audience with a wide age range.
\end{abstract}

Keywords: Character Design, Mascot, Anthropomorphism, Malang city

\begin{abstract}
Abstrak: Daya pikat dibutuhkan untuk mengalihkan perhatian audiens kepada desain, walaupun hanya sesaat. Daya pikat ini terdapat dalam semua bidang desain, terutama desain karakter. Salah satu contoh desain karakter adalah maskot. Malang merupakan kota pertama yang memiliki maskot yang dibuat dengan prosedur yang ideal, hasil dari kerjasama ADGI (Asosiasi Desainer Grafis Indonesia) Chapter Malang dengan Barenlitbang Kota Malang. Osi dan Ji adalah Maskot Kota Malang dengan bentuk anthropomorphism dari hewan singa dan burung manyar sebagai lambang kota Malang. Penelitian ini mengkaji desain karakter maskot tersebut menggunakan prinsip karakter desain, yaitu: silhoutte, shape, proportion dan pose. Data yang didapat dari hasil observasi, wawancara, dan dokumentasi desain karakter maskot Kota Malang dikaji dengan metode kualitatif dengan pendekatan analisis visual. Keempat prinsip desain saling menguatkan keseluruhan makna bahasa visual yang terdapat pada desain karakter maskot tersebut sehingga daya pikatnya tinggi terhadap khalayak sasaran dengan rentang usia yang luas.
\end{abstract}

Kata kunci: Desain karakter, maskot, anthropomorphism, Kota Malang

Desain sengaja dibuat dengan daya pikat yang tinggi walaupun itu hanya untuk momen yang singkat. Desain yang demikian disebut dengan desain yang afektif dan menyenangkan. Salah satu contoh perkembangan desain yang afektif dan menyenangkan dapat dilihat pada bidang desain karakter. Desain karakter dapat memiliki identitas dan nilai jual tersendiri, Hal ini dapat dilihat pada contoh modern, seperti karakter Mickey Mouse yang merupakan gambar/karakter paling terkenal di seluruh dunia. Mickey Mouse berhasil mengubah penampakan visual tikus sebagai hewan yang kurang menarik dengan bentuk melingkar dan bulat (Marcus, et.al., 2017:4). Lebih lanjut disebutkan, bahwa bentuk tersebut kini menjadi lebih sederhana dan ikonik, Mickey Mouse dapat dikenali hanya dari tiga lingkaran yang saling berpotongan. Begitu kuat kesan visual yang dapat diciptakan dari sebuah desain karakter, sehingga dapat digunakan sebagai representasi sebuah identitas pada maskot. Maskot merupakan representasi visual yang mencakup keseluruhan identitas dari stakeholder baik itu produk, perusahaan ataupun komunitas. Berbagai maskot diciptakan untuk membantu proses komunikasi kepada khalayak 
sasaran, tujuannya untuk menggerakkan emosi positif dengan penampilan visual. Menurut Hotogi (Hotogi \& Hagiwara, 2015) ada beberapa kata afektif yang didapat dari analisis desain karakter maskot lokal yang ada di jepang, seperti: cheerful, simple, amiable, humorous, gentle, innocent, cute, gorgeous, carefree. Kata-kata ini yang nantinya dapat diterjemahkan dengan menggunakan bahasa visual, dengan demikian karakter akan memiliki tampilan yang afektif dan menarik. Joel (Gn, 2016) menyebutkan bahwa afeksi tersebut memberikan alasan untuk sebuah obyek dapat disebut 'cute'.

Kesan visual ini dimaknai sebagai sesuatu yang penting dan memiliki dampak positif oleh pemerintah Kota Malang, sehingga pada Oktober 2016 Barenlitbang Kota Malang berkerjasama dengan ADGI (Asosiasi Desainer Grafis Indonesia) Chapter Malang mengadakan lomba desain maskot Kota Malang. Lomba tersebut menghasilkan dua karakter maskot yang merupakan sebuah kesatuan, bernama Osi dan Ji. Keduanya merupakan personifikasi dari hewan yang dianggap mewakili Kota Malang. Osi merupakan personifikasi dari Singa, sedangkan Ji merupakan personifikasi dari Burung Manyar. Perlu dikaji lebih lanjut bagaimana prinsip desain karakter pada maskot tersebut.

\section{MASKOT KOTA MALANG}

Salah satu penerapan desain karakter adalah pada karakter official atau yang sering disebut dengan istilah maskot. Masyarakat di berbagai belahan dunia suka dengan maskot yang imut, tetapi keberadaannya di Jepang merupakan sesuatu yang unik. Di Jepang maskot dikenal sebagai 'yuru-kyara' (karakter yang lemah) sebuah istilah yang digunakan seniman dan akademisi dalam bidang karakter desain Jun Miura untuk menandakan fakta bahwa penggunaan mereka terbatas. Masyarakat jepang memiliki bakat untuk mengenalkan maskot di segala situasi yang mungkin dianggap tidak tidak masuk akal atau bahkan tidak menjadi pertimbangan di negara lainnya. Seperti menggunakan maskot yang imut pada departemen kepolisian atau pertahanan negara di Jepang. Masyarakat di negara selain Jepang mungkin akan menganggap hal ini sebagai sesuatu yang merendahkan nilai dari konsep formal. Di Jepang penggunaan maskot yang seringkali mengejutkan ini membuat kemampuan maskot untuk membentuk suasana yang rileks dan menghibur lebih teruji (Alt \& Yoda, 2007). Lebih lanjut dikatakan bahwa masing-masing kota di Jepang memiliki maskot sendiri, sebagai contoh yang paling popular adalah Kumamoto dengan maskotnya Kumamon. Hal ini yang mungkin dibidik oleh Asosiasi Desain Grafis Indonesia (ADGI) Chapter Malang sebagai salah satu upaya branding Kota Malang.

Barenlitbang Kota Malang bersama ADGI Chapter Malang pada tahun 2016 mengadakan sebuah lomba desain maskot kota dengan metode procedural. Pada lomba ini, tahap pertama panitia mengadakan seleksi desainer karakter lewat portofolio; tahap kedua panitia melakukan briefing pada 25 desainer terpilih; tahap ketiga pelaksanaan lomba dilakukan dengan rentang waktu dua minggu; tahap keempat 25 desainer terpilih melakukan presentasi didepan dewan juri; serta tahap kelima dipilihlah satu pemenang yang paling representatif desainnya, yaitu desain maskot Kota Malang yang bernama Osi \& Ji.

Penamaan Osi \& Ji (Jakfar, 2017) diambil dari bahasa malang (bahasa walikan). 'Osi' dari 'Iso' yang berarti 'Bisa' dan 'Ji' diambil dari 'Siji' yang berarti 'Satu'. Nama ini memiliki arti bahwa warga Kota Malang bisa bersatu demi mencapai satu tujuan. Osi merupakan personifikasi dari Singa sebagai lambang Kota Malang pada jaman penjajahan Belanda, sedangkan Ji merupakan personifikasi dari Burung Manyar sesuai dengan SK Gubernur nomor 5225/16774/032/1996 sebagai ciri khas fauna Kota Malang. Visualisasi Osi \& Ji dapat dilihat pada gambar 1.

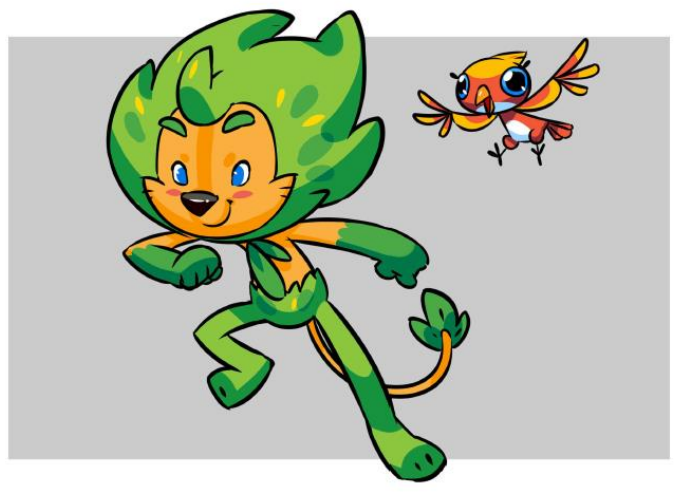

Gambar 1 Osi dan Ji

Sumber: Jakfar, 2017:6

\section{PRINSIP DESAIN KARAKTER}

Desain karakter merupakan sebuah proses representasi dari emosi/sifat manusia yang memiliki tujuan tertentu. Dalam proses 
penciptaannya, sebuah desain karakter secara visual harus tampak 'hidup' layaknya manusia. Pada dasarnya desain karakter merupakan perkembangan dari akting. Sebuah aktor harus dapat merasakan perasaaan karakter yang diperankannya, yang kemudian disampaikan melalui gesture dan ekspresi yang otentik. Pada awal abad ke-20, aktor Rusia Constantin Stanislavski menemukan bagaimana seorang aktor dapat mengakses emosi manusia dan mengeskpresikannya di panggung kepada penonton. Stanislavski kemudian menyebut hal ini dengan Theory of Psycho-Physical Action, bahwa seorang aktor dapat membuat inner life atau inti dari emosi dari karakter apapun menggunakan dua elemen; psychological mind dan physical body (Sullivan, Schumer, \& Alexander, 2008:70). Lebih lanjut dikatakan bahwa psychological mind adalah gambaran di otak yang menciptakan emosi, sedangkan physical body adalah gestur dan pergerakan yang merefleksikan gambaran di otak tersebut. Sehingga, sebuah desain karakter yang kuat, tidak hanya tampil baik secara visual, tetapi juga harus dapat menggambarkan emosi manusia.

Desain karakter yang kuat merupakan desain yang dapat mudah dipercaya dan mudah diingat. Karakter yang mudah dipercaya merupakan karakter yang cukup biasa tetapi memiliki situasi yang tidak biasa, sehingga khalayak sasaran dapat menghubungkan karakter tersebut dengan dirinya. Sedangkan karakter yang mudah diingat adalah karakter yang secara visual menarik dan dapat menggerakkan emosi khalayak sasaran. Thomas dan Johnston (Thomas \& Johnston, 1981:68) menyebut hal tersebut dengan istilah appeal. Menurut mereka appeal adalah jika mata penonton tertarik terhadap sebuah desain karakter dan mengapresiasi apa yang dilihatnya tersebut. Lebih lanjut dikatakan bahwa karakter bisa saja cantik atau jelek, rumit atau polos, baik atau buruk, selama karakter tersebut memiliki appeal (daya tarik), maka penonton selalu ingin mengetahui lebih jauh tentang karakter tersebut. Sebuah desain karakter yang memiliki daya tarik tidak akan lengkap tanpa kepribadian yang memikat.

Dalam memberikan daya Tarik pada desain karakter dibutuhkan prinsip desain. Terdapat 4 prinsip desain yang dapat digunakan dalam merancang sebuah karakter, yaitu: Silhoutte, Shape, Proportion dan Pose (Pontillas, 2011). Silhoutte (siluet) merupakan outline (gambaran umum) sebuah karakter. Karakter harus tampak berbeda dengan karakter yang sudah pernah ada agar karakter berbeda dan unik. Selain itu, dengan siluet yang khas karakter dapat dikenali dengan mudah. Shape (bentuk) dasar memiliki makna yang berbeda sesuai dengan bahasa visualnya, seperti kotak yang memiliki makna kuat dan kokoh. Penggunaan bentuk yang kontras dapat membuat karakter lebih menarik. Proportion (proporsi) dapat ditentukan melalui ladder effect, artinya proporsi dapat diubah sesuai dengan sifat yang direpresentasikan karakter. Pose berfungsi untuk mengempasis desain, ketika penggunaannya sesuai dengan prinsip lainnya.

\section{METODE}

Penelitian ini akan menggunakan metode kualitatif yang dilakukan mulai tahap pengumpulan data, tahap analisis dan tahap interpretasi. Data berupa desain karakter maskot Kota Malang akan dikumpulkan dengan format gambar, dilanjutkan dengan proses analisis melalui empat prinsip karakter desain, yaitu: silhoutte, shape, proportion, dan pose. Data akan dianalisis secara visual, yang dilakukan dengan prosedur secara berurutan mulai dari deskripsi, analisis, interpretasi dan judgement (Soewardikoen, 2013:39). Pengumpulan data dilakukan dengan cara observasi pada desain karakter maskot Kota Malang, kemudian wawancara kepada desainer maskot Kota Malang yaitu Papang Jakfar, serta pengumpulan dokumentasi desain karakter maskot Kota Malang.

\section{PEMBAHASAN}

Desain karakter maskot Kota Malang bernama Osi dan Ji. Osi adalah karakter personifikasi dari singa, sedangkan Ji adalah karakter personifikasi dari burung manyar. Personifikasi dalam desain lebih dikenal dengan istilah anthropomorphism - perlambangan karakteristik fisik dan perilaku manusia kepada hewan atau benda yang tidak hidup (Geerdts, Van de Walle, \& LoBue, 2016). Anthropomorphism sering digunakan dalam media, terutama media untuk anak-anak seperti buku cerita bergambar. Karakter anthropomorphic akan dilihat sebagai sesuatu yang baru dan tidak berhubungan dengan hewan atau manusia di dunia nyata, mereka adalah sebuah karakter utuh yang memiliki bentuk dan kepribadian, serta dapat berinteraksi dan berkomunikasi kepada audiensnya. 
Pada gambar berikut, dapat dilihat tampilan visual dari Osi dan Ji sebagai karakter maskot Kota Malang.

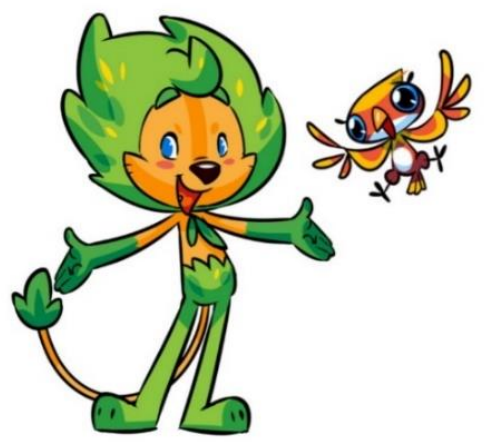

Gambar 2 Osi dan Ji

Sumber: Jakfar, 2017:9

Dilihat dari tampilan visualnya, Osi adalah karakter singa dengan warna tubuh kuning dan surai berwarna hijau. Berdasarkan hasil wawancara dengan narasumber pada tanggal 17 April 2018, diketahui latar belakang cerita Osi. Osi adalah seekor singa penjaga Kota Malang yang mendapatkan warna hijaunya dari meditasi yang lama, dan sampai akhirnya di beberapa bagian badan Osi ditumbuhi dedaunan. Pada surai Osi terdapat bentuk visual menyerupai daun berwarna hijau tua dan kuning. Osi memiliki mata berwarna biru, dan hidung berwarna hitam. Warna hijau juga terdapat pada bagian tangan dan kaki, serta pangkal ekor. Surai dan Ekor Osi memiliki bentuk yang menyerupai bentuk dedaunan.

Ji adalah karakter burung manyar dengan warna tubuh kuning dan oranye. Ji memiliki mata berwarna biru sama seperti Osi. Terdapat warna putih di bagian bawah kepala dan perut. Menurut latar belakang ceritanya, Ji adalah karakter yang membantu Osi untuk bangun dari meditasi lamanya, dan mereka kemudian bersama-sama menjaga Kota Malang.

Pada tampilan visual tersebut Osi dan Ji menampilkan pose "Halo!" yaitu pose untuk mengkomunikasikan selamat datang di Kota Malang. Selain pose tersebut ada lima pose lainnya yaitu: pose "polisi", pose "buku", pose "skate", pose "hormati" dan pose "hore". Pada gambar berikut secara berurutan dari kiri ke kanan dapat dilihat kelima pose tersebut.

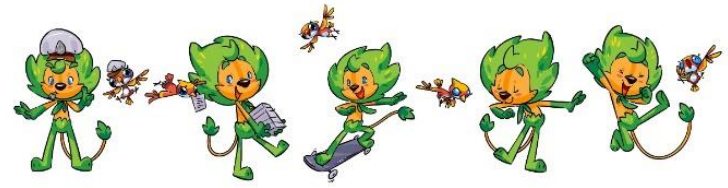

Gambar 3 Pose Alternatif Osi dan Ji

\section{Sumber: Jakfar, 2017: 9-12}

Pose "hormati" dan pose "hore" adalah alternatif dari pose "halo" sebagai pose maskot yang ramah kepada audiens. Sedangkan tiga pose lainnya dibuat untuk mewakili kegiatan yang mungkin akan dibawakan oleh maskot, dengan fungsi maskot sebagai ambasador kegiatan pemerintahan. Contoh kegiatan tersebut seperti: polisi cilik dan keamanan berkendara, gerakan membaca, serta aktivitas luar ruangan dan olahraga.

Pada buku GSM tersebut juga terdapat gambar tampak dari karakter Osi dan Ji. Gambar tampak tersebut terdiri dari gambar tampak depan, gambar tampak belakang, gambar tampak samping dan gambar tampak atas. Gambar tampak ini ditampilkan sebagai panduan ketika ada desainer atau pihak lain yang ingin menggunakan maskot Kota Malang pada sebuah kegiatan yang tidak dapat diwakilkan oleh kelima pose di atas. Berikut adalah gambar tampak Osi.

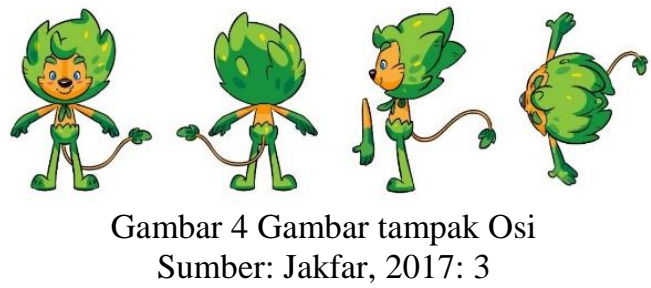

Sedangkan gambar berikut adalah gambar tampak dari karakter Ji.

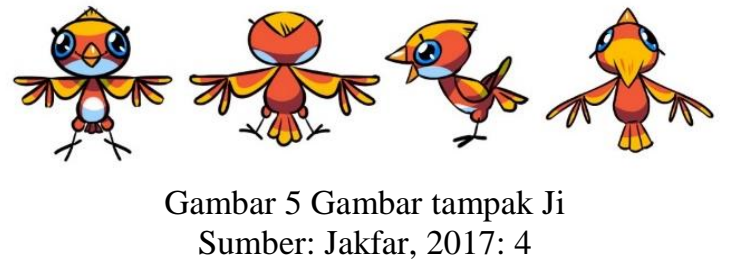

Bisa dilihat bahwa pada kedua gambar tampak tersebut karakter Osi dan Ji menggunakan proporsi badan manusia, dengan perbandingan sebagai berikut; Osi menggunakan proporsi empat kepala, sedangkan Ji menggunakan proporsi dua kepala.

Penerapan maskot dapat disesuaikan dengan kampung tematik yang ada di Malang. Surai dari Osi dapat berubah warna dan tekstur sesuai dengan tema kampung tematik yang diwakilinya. Sub maskot kampung tematik tersebut dapat dilihat pada gambar berikut. 


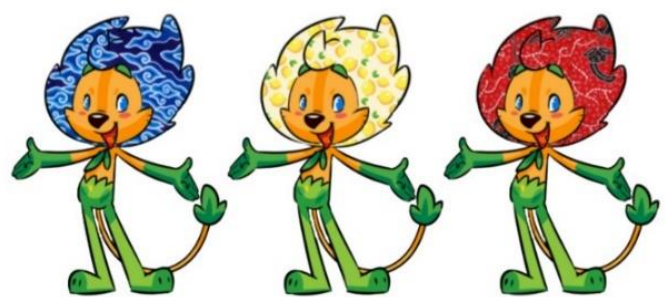

Gambar 6 Sub maskot kampung tematik. Sumber: Jakfar, 2017: 4

Perlu diketahui bahwa desain sub maskot ini masih sekedar konsep desain, belum ada implementasi lebih lanjut dari pemerintah mengenai lambang atau simbol yang akan digunakan pada kampung-kampung tematik yang dimiliki Kota Malang.

Daya tarik yang dimiliki desain karakter maskot Kota Malang dapat dikaji melalui teori prinsip desain karakter. Sebagaimana telah dipaparkan pada bab kajian teori, bahwa terdapat empat prinsip desain karakter yaitu silhoutte, shape, proportion dan pose. Silhoutte merupakan gambaran umum desain karakter yang dapat menciptakan bahasa tanda visual yang khas. Dengan demikian, hanya dengan silhoutte saja desain karakter dapat dikenali dan dibedakan dengan desain karakter lainnya. Berikut adalah gambar silhoutte dari Osi dan Ji.

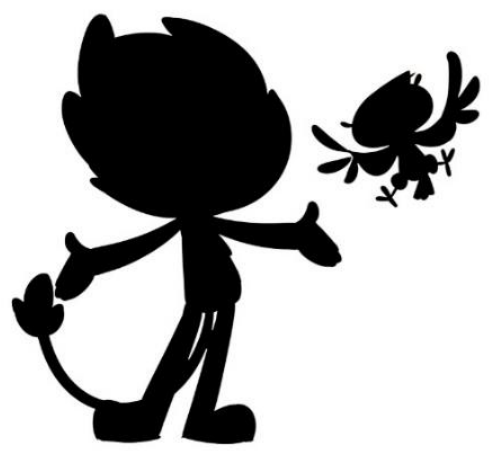

Gambar 7 Silhoutte Osi dan Ji Sumber: Dokumentasi Penulis

Melalui tampilan visual silhoutte tersebut dapat diidentifikasi dengan mudah bahwa Osi adalah karakter yang memiliki rambut pada bagian kepala dan ekor, dapat diasosiasikan dengan bentuk hewan yang memiliki ciri tersebut, yaitu singa. Dari silhouttenya dapat dilihat bentuk rambut yang menyerupai dedaunan khas yang melekat pada ciri desain karakter Osi. Silhoutte desain karakter Osi juga memperlihatkan semua anggota tubuh secara jelas, tidak ada bagian tubuh yang tertutupi atau hilang. Dengan demikian pose dari karakter dapat terbaca dengan mudah oleh mata target audiens. Secara silhoutte desain karakter Osi sudah dapat dibedakan dengan desain karakter singa lain.

Silhoutte desain karakter Ji juga dapat diidentifikasi dengan mudah, bahwa karakter tersebut adalah hasil anthropomorphism dari hewan burung. Bentuk tangan yang menyerupai sayap mempertegas hal tersebut. Serupa dengan desain karakter Osi, desain karakter Ji memperlihatkan anggota tubuh secara jelas dan posenya dapat terbaca dengan mudah. Secara silhoutte desain karakter Ji sudah dapat dibedakan dengan desain karakter burung lainnya.

Prinsip yang kedua adalah shape. Dilihat dari tampilan visual shape (bentuk) desain karakter Osi dan Ji banyak menggunakan bentuk lingkaran. Bentuk lingkaran tersebut dapat dilihat pada gambar berikut.

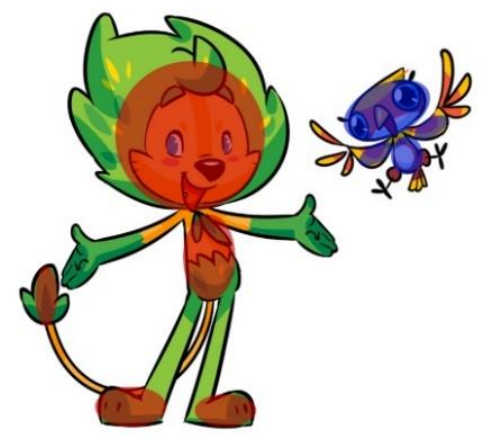

Gambar 8 Basic shape pada Osi dan Ji Sumber: Dokumentasi Penulis

Menurut hasil wawancara kepada narasumber tanggal 25 September 2018, disebutkan bahwa pada saat perancangan desain maskot digunakan formula basic shape sebagai elemen desainnya. Basic shape mulai dari kotak, segitiga dan lingkaran memiliki karakteristik bahasa visual tersendiri. Sebagai contoh bentuk lingkaran mempunyai makna cute dan approachable. Penggunaan bentuk ini muncul dari kata kunci yang didapat dari proses perancangan maskot, yaitu salah satunya adalah kata "ramah". Maskot memiliki fungsi untuk menyampaikan pesan yang harus diterima oleh khalayak sasaran, maka dari itu terlebih dahulu harus memiliki kedekatan emosional. Kedekatan emosional tersebut dapat dicapai dengan Osi dan Ji karena bentuknya didominasi oleh lingkaran atau garis lengkung.

Prinsip desain karakter yang ketiga adalah proportion (proporsi). Proporsi merupakan perbandingan satu bagian terhadap bagian lainnya, pada desain karakter proporsi badan biasanya dihitung berdasarkan besar kepala. Proporsi akan 
menceritakan tentang personality karakter. Karakter dengan proporsi badan bagian atas lebih panjang daripada badan bagian bawah akan menceritakan personality yang maskulin. Sebaliknya, karakter yang yang memiliki proporsi badan bagian bawah yang lebih panjang daripada badan bagian atas akan menceritakan personality yang feminin. Desain karakter yang menggunakan proporsi badan dengan panjang yang sama pada bagian atas dan bawah akan menceritakan personality yang generic (umum), dalam artian karakter tersebut tidak memiliki personality yang mengarah pada satu sifat tertentu. Berikut adalah gambar proporsi dari Osi dan Ji.

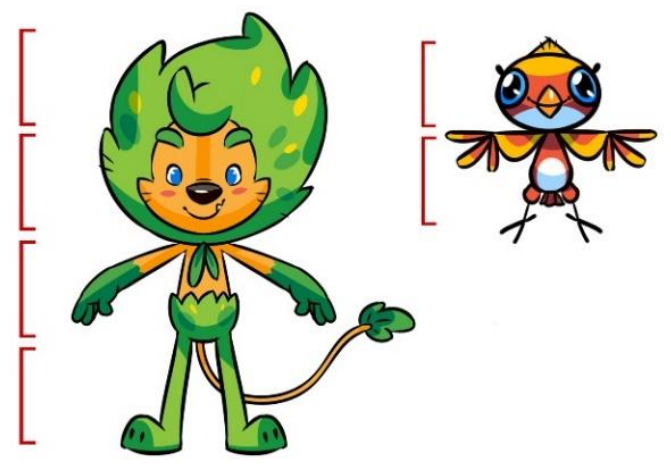

Gambar 9 Proporsi Osi dan Ji Sumber: Dokumentasi Penulis

Jika dilihat dari proporsinya Osi dan Ji masing-masing menggunakan proporsi empat kepala dan dua kepala. Proporsi Osi menggunakan hitungan dua kepala pada bagian kepala Osi, sehingga bagian kepala terlihat lebih besar daripada bagian badan dan kaki. Hal ini membuat karakter tersebut terlihat imut dan lucu. Proporsi badan empat kepala menunjukkan proporsi badan anak-anak sekitar umur 6-7 tahun. Proporsi badan dan kaki Osi menggunakan perbandingan proporsi yang sama, sehingga karakter ini menceritakan personality umum. Personality yang umum biasanya digunakan pada karakter utama (Lewis, 2018: 14). Jika dilihat lebih lanjut, proporsi Osi dan Ji memberikan makna enerjik dan lincah. Proporsi Ji hanya menggunakan perbandingan dua kepala, sehingga perbandingan kepala dan badan sama besar, hal ini menunjukkan proporsi badan bayi. Proporsi yang seperti ini membuat desain karakter Ji memiliki tingkat keimutan yang lebih tinggi daripada desain karakter Osi. Bentukan ini menegaskan bahwa desain karakter Ji bukanlah karakter yang utama.
Prinsip desain karakter yang keempat adalah pose. Pose dalam desain karakter digunakan untuk menekankan ketiga prinsip lainnya pada karakter, sehingga karakter terkesan hidup dan meyakinkan. Pose harus digambarkan secara jelas, dalam artian pose tersebut tidak memiliki makna ganda. Pose yang baik memiliki line of action yang dinamis. Line of action adalah garis imajiner yang merupakan aksi utama dari karakter (Blair, 1949:5). Lebih lanjut dikatakan bahwa dengan menggunakan line of action akan menambah efek dramatis dari pose. Berikut adalah tampilan visual enam pose Osi dan Ji beserta line of actionnya.

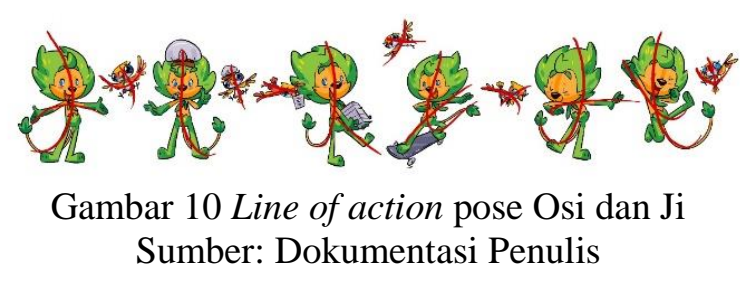

Line of action yang dinamis cenderung memiliki jenis garis yang melengkung. Apabila dilihat dari proses penciptaannya, garis ini digunakan sebagai panduan menggambar keseluruhan pose. Bagian ekor Osi dan Ji merupakan perpanjangan dari badan dan merupakan kesatuan desain, maka dari itu line of action akan diteruskan sampai pangkal ekor. Jika dilihat lebih lanjut, bisa terdapat line of action lebih dari satu dari pose Osi dan Ji. Line of action sekunder ini dibutuhkan untuk memberikan keseimbangan visual terhadap pose tersebut.

\section{KESIMPULAN}

Daya tarik yang dimiliki desain karakter Osi dan Ji dikaji melalui empat prinsip desain karakter yaitu: silhoutte, shape, proportion dan pose. Osi dan Ji memiliki silhoutte yang unik, yang dapat membedakan dengan desain karakter yang lainnya. Bentuk yang banyak digunakan adalah bentuk lingkaran memberikan makna yang cute dan approachable. Dilihat dari proporsinya, Osi dan Ji menggunakan proporsi anak-anak dan bayi dengan type personality yang enerjik dan lincah. Pose Osi dan Ji menggunakan line of action yang dinamis, sehingga didapat pose yang jelas. Keempat prinsip tersebut saling menguatkan keseluruhan makna bahasa visual yang terdapat pada desain karakter maskot tersebut, sehingga Osi dan Ji memiliki daya tarik yang tinggi. Penelitian ini hanya berfokus pada faktor internal desain karakter maskot, dapat dilakukan 
penelitian lanjutan dengan fokus faktor external seperti persepsi target audiens terhadap desain karakter maskot tersebut.

\section{REFERENSI}

Alt, M., \& Yoda, H. (2007). Hello, Please! Very Helpful Super Kawaii Characters from Japan. San Francisco: Chronicle Books LLC.

Blair, P. (1949). Advanced Animation: Learn How to Draw Animated Cartoons. Walter T. Foster.

Geerdts, M. S., Van de Walle, G. A., \& LoBue, V. (2016). Learning About Real Animals From Anthropomorphic Media.

Imagination, Cognition and Personality, $36(1), 5-26$.

https://doi.org/10.1177/0276236615611798

Gn, J. (2016). A lovable metaphor: On the affect, language and design of 'cute.' East Asian Journal of Popular Culture, 2(1), 49-61. https://doi.org/10.1386/eapc.2.1.49_1

Hotogi, M., \& Hagiwara, M. (2015). Analyses of
Local Mascot Characters and Proposal of Automatic Character Creation System Using Affective Words. International Journal of Affective Engineering, 14(4), 299-307. https://doi.org/10.5057/ijae.IJAED-14-32

Jakfar, P. (2017). The Mascot. Barenlitbang Kota Malang.

Lewis, M. (Ed. . (2018). Creating Stylized Character Design. Worcester: 3Dtotal Publishing.

Marcus, A., \& Hashizume, Masaaki, Ma, Xiaojuan, H. A. (2017). Springer Series on Cultural Computing Cuteness Engineering.

Pontillas, B. (2011). Design Presentation.

Soewardikoen, D. W. (2013). Metodologi Penelitian Visual. (M. Saputra, Ed.) (First). Bandung: CV Dinamika Komunika.

Sullivan, K., Schumer, G., \& Alexander, K. (2008). Ideas for the Animated Short: Finding and Building Stories. Elsevier Inc. Thomas, F., \& Johnston, O. (1981). The Illusion of Life. New York: Walt Disney Production. 